УДК 004.05:37.061.001.2(477)

Пірко Марина Василівна, молодший науковий співробітник Інституту інформаційних технологій і засобів навчання НАПН України, м. Київ

\title{
ДИДАКТИЧНІ ПРИНЦИПИ І ПСИХОЛОГІЧНІ ЧИННИКИ У ВИЗНАЧЕННІ ЯКОСТІ ПРОГРАМНИХ ЗАСОБІВ НАВЧАЛЬНОГО ПРИЗНАЧЕННЯ
}

\section{ЗАГАЛЬНООСВІТНЬОГО СЕРЕДОВИЩА В УКРАЇНІ}

\author{
Анотація \\ Фундаментальною особливістю економіки постіндустріального суспільства $є$
} те, що знання є головним джерелом конкурентної переваги. У статті розглянуто й описано коло дидактичних, психологічних чинників у дослідженнях проблем досягнення високого рівня якості освіти й освітніх послуг. Звернуто увагу на тимчасові педагогічні вимоги, які є нормативним обгрунтуванням в орієнтаціях на визначення якості програмних засобів навчального призначення загальноосвітнього середовища в Україні на сучасному етапі створення єдиного освітнього простору. Розглянуто схему внутрішньої моделі забезпечення якості програмних засобів навчального призначення, перелічено певну кількість аспектів, які інтегрує в собі внутрішня модель якості програмних засобів навчального призначення. Вказано на основні принципи щодо організації педагогічних програмних засобів навчання. Описано спрямування досліджень в умовах формування глобального міжнародного освітнього середовища і єдиного інформаційного простору системи освіти, в умовах зростання рівня доступності освіти, і набуття соціального характеру проблемою визначення рівня якісної освіти.

Ключові слова: глобальне міжнародне освітнє середовище (ГМОС), Державний Освітній Стандарт (ДОС), єдиний інформаційний простір системи освіти (ЄIПСО), програмні засоби навчального призначення (ПЗНП), дидактичні принципи, психолого-педагогічні вимоги, оцінка якості, якість освіти.

Економічна наука розглядає сучасний етап розвитку суспільства як перехід від індустріального суспільства до постіндустріального, якому притаманні такі властивості як збільшення долі творчої й інтелектуальної праці, зростання обсягів наукових знань і застосування їх на виробництві, а також перевагою сфери послуг, 
науки, освіти і культури над промисловістю і сільським господарством у структурі економіки. Ситуація, що знання - це джерело конкурентної переваги, обумовлена інтенсивним розвитком технологій і впровадженням результатів технологічного прогресу на виробництві й у сфері послуг, що пов’язано 3 посиленням орієнтації праці на інтелектуальну діяльність, що значно знижує потребу економіки у некваліфікованій праці, а вимоги щодо більшості місць праці ускладнюються [2].

Важливим фактором для визначення ознак щодо професійних якостей спеціаліста на сучасному етапі $\epsilon$ рівень технологічності виробничих процесів. Значною мірою, як нові технології витісняють некваліфіковану рутинну працю, ресурси людства мобілізуються на творчу працю, пов’язану з прийняттям рішень, що вимагає відповідного рівня інтелектуальної і професійної підготовки. У зв’язку з цим необхідно виділити два стрижневих аспекти розвитку:

- розвиток творчого мислення і мета когнітивних навичок;

- забезпечення доступу до ресурсів даних, необхідних для прийняття рішень в різноманітних галузях.

Відповідно, необхідною характеристикою рівня підготовки сучасних спеціалістів є оволодіння інформаційними технологіями, i, зрозуміло, технологіями конкретних місць праці. Другим важливим фактором формування характеристики спеціаліста $\epsilon$ розвиток i використання новітніх методологічних підходів, обгрунтоване результатами наукових досліджень із різних галузей виробничої i господарської діяльності, використання нових методик, що дозволяють підвищення якості послуг, що надаються. I це в той самий час, коли спостерігається різке скорочення циклів створення більшості розробок і досліджень. I також в умовах інтенсивного старіння знань, придбаних фахівцями під час підготовки (навчання).

В умовах переходу до економіки, підгрунтям якої $\epsilon$ знання, управління знаннями стає найважливішою функцією управління, що притаманно даному етапу розвитку. Управління знаннями уособлює логічно послідовний підхід до виявлення і визначення знань, необхідних установі для досягнення розв'язання конкретних задач [10], зв'язок фундаментальних питань із формуванням знань, а також розподілом їх, розповсюдженням і використанням, обумовленість створення нових знань інтенсивною динамікою сучасного суспільства на даному етапі розвитку в цілому. Тому актуальність проблеми якості знань аксіоматична. Потоки повідомлень 
формуються в умовах змін об’єктів економіки і трансформації зв’язків між об'єктами. Розповсюдження знань певними об’ємами і є стрижневою функцією сучасних IКТ.

Широке використання комп`ютерних i телекомунікаційних інформаційних технологій (IT) просуває розвиток їх у всіх сферах діяльності й відносин людей, i впливає на формування нового явища глобального міжнародного освітнього середовища (ГМОС), і єдиного інформаџійного простору системи освіти (ЄІПСО) [1, c. 61], в умовах скорочення життєвого циклу знань і цим обумовленої необхідності безперервного навчання фахівців різного рівня. Саме швидка зміна поколінь техніки i технологій, що випереджає зміну активно діючого покоління людей, які безпосередньо або опосередковано взаємодіють з ними, і є в числі проблем процесу розвитку систем освіти і Росії, і Білорусі, й інших зарубіжних країн, що відображають особливості еволюції та специфіку динаміки розвинення і стану кожної держави окремо.

Явище незадоволеності якістю освіти й освітніх послуг має глибокі коріння у стрімкому зрості обсягу цікавих i корисних фактів науково-технічної сфери i визначній ролі інтелектуального потенціалу держави в конкурентних відносинах на світовому ринку. Проблема якості є центральною проблемою епохи глобалізації. Зростання якості освіти й освітніх послуг розширює можливості становлення сучасної, так званої інформаційної цивілізації. I тому процес оновлення i «осучаснювання» на основі новітніх технологій через впровадження в навчальновиховний процес IКТ, а також - формування в молоді рис, необхідних для успішної самореалізації в інформаційному суспільстві після завершення навчання в школі...» $€$ найскладнішим двоєдиним завданням перед освітою, наголошується в [7].

Можливості використання інформаційно-комунікаційних технологій у середніх загальноосвітніх навчальних закладах у процесі інформатизації освіти дозволили підвищення ефективності навчання, вивели якість подання навчального матеріалу на новий рівень, утворили можливості вдосконалення педагогічної майстерності викладачів i вдосконалення процесу навчання для учнів. Зростання обсягів виробництва програмних засобів навчального призначення (ПЗНП), як загальновизнаними лідерами, так і окремими дослідниками, або дослідницькими групами сягнув максимальних обсягів: «1С», «Кирило і Мефодій», «Інтелект-Сервіс», «Інком», «Політек-Софт», «Сходинки до інформатики», «Фізікон», та ін. У цьому 
числі і розроблений у 1989 році М. І. Жалдаком і його аспірантами комплекс для підтримки навчання математики Gran [3], i розробки колективів Херсонського державного університету, Харківського державного педагогічного університету ім.. Г. С. Сковороди, Інституту педагогіки НАПН України, Інституту проблем штучного інтелекту МОН і НАН України, розробки компаній «Квазар-Мікро Техно», «ІНТО», ЗАТ «Мальва» та ін. Більшість розробок програмного забезпечення й електронних засобів для освіти навчальні заклади здійснюють самостійно. I в цій безлічі різноманітної програмної продукції на сучасному ринку високоякісні електронні засоби навчального призначення виокремити проблематично. Підстав для такого роду міркувань на теперішньому етапі розвитку достатньо:

- згідно стандартів ICO 9001 під якістю програмного забезпечення розуміють характеристику програмного забезпечення як ступінь відповідності програмного забезпечення вимогам, i саме трактування вимог досить широко, що реально дає певну кількість незалежних означень цього поняття;

- окрім того, зв'язок терміну оцүінка (assessment) із трактуванням як «встановлення відповідності», конкретно подібний за термінологізацією до оцінювання (evaluation) (ДСТУ ISO 9000-2001), звідки аксіоматично випливає встановлення відповідності певним вимогам;

- тобто, оцінка якості, у будь якому варіанті - компонент системних погоджень, який завжди породжує дискусії, тим більше в процесі формування нового явища глобального міжнародного освітнього середовища (ГМОС), і єдиного інформащійного простору системи освіти (ЄІПСО), необхідно уточнення так званих критерїв якості. Стрижневою ланкою в організації системи якості при створенні ПЗНП є формування внутрішньої моделі якості. 


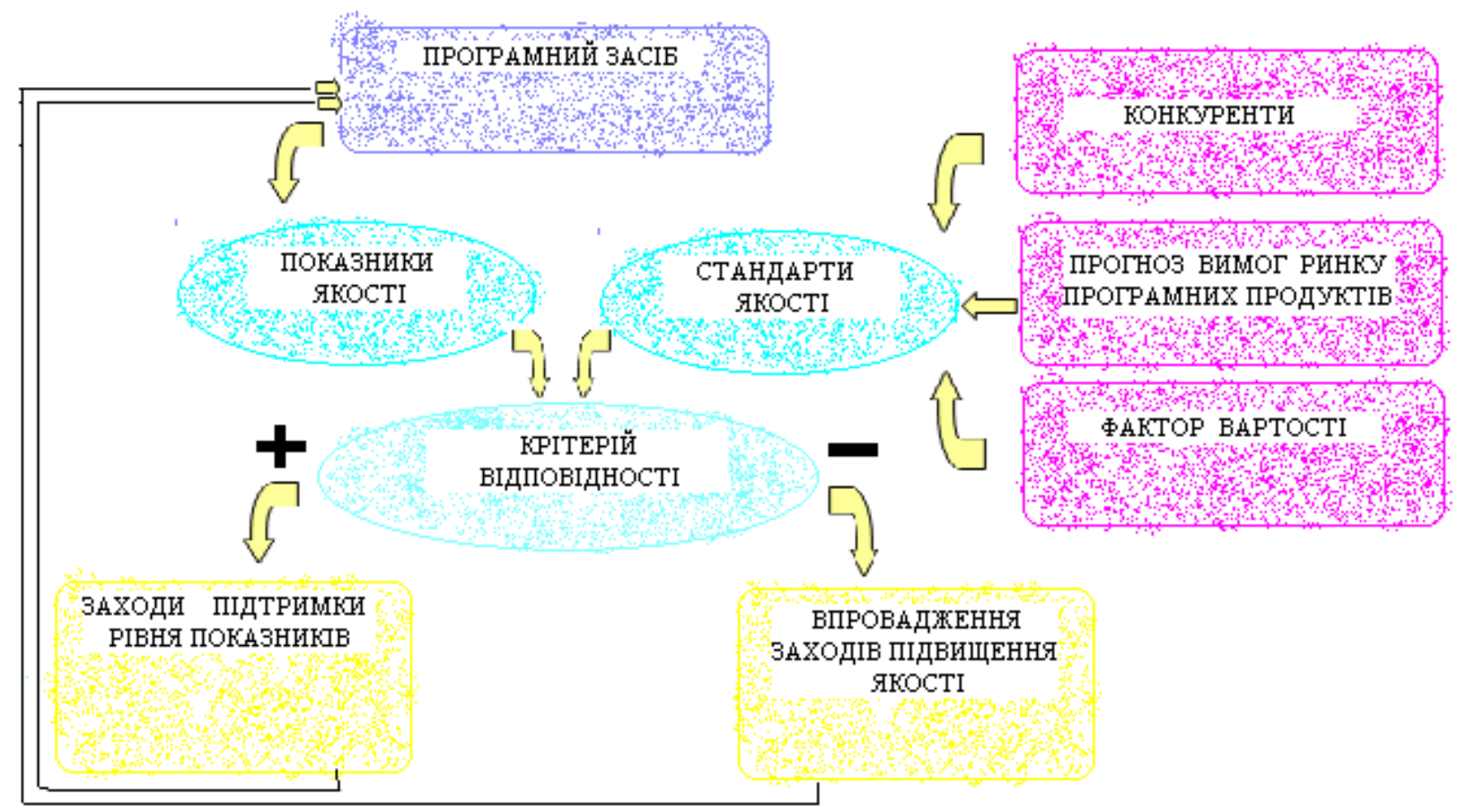

Рис. 1. Схема забезпечення якості програмного засобу навчального призначення

Внутрішня модель якості інтегрує певну кількість аспектів, серед них: якість навчального матеріалу; якість навчальних технологій; якість потенціалу учнів; якість потенціалу викладачів; якість навчально-методичного, матеріально-технічного ресурсів; якість освітніх процесів; якість персоналу управління; ефективність управління; і ще багато ін. Структурно це може бути представлено як на рис. 1, структурні частини моделі взаємопов’язані, але кожна частина має свої особливості розвитку, свої складнощі, потребує своїх ресурсів, тому має розвиватися згідно 3 планом. Саме погодження між структурними компонентами викликають ключові проблеми.

Також слід звернути увагу, що засоби навчального призначення створювалися за відсутності чітко встановленого методологічного, дидактичного і нормативного обгрунтувань. Ймовірно, без урахування психолого-педагогічних закономірностей навчання й учіння, без врахування специфіки перебігу психічних процесів, закономірностей обробки й сприйняття повідомлень, поглиблюється вірогідність похибок в оцінках психічних функцій учнів і т. п.

Зрозуміло, що об’єкти такого масштабу потребують системного дослідження, оскільки під впливом інформаційно-комунікаційних технологій змінюється структура навчального середовища, типи навчальних взаємодій, комунікації навчального середовища. I засоби виявляються мінімально дослідженими компонентами 
педагогічних і дидактичних систем, беручи до уваги новизну і складність IКТ. Особливо слід приділити увагу багатьом аспектам безпеки ПЗНП, у тому числі нормам обсягів навчальних повідомлень з метою уникнення використання надмірних обсягів навчальних даних, запобігання можливості невідповідності змісту матеріалу віку і індивідуальним можливостям дитини, проблем психологічної комфортності під час взаємодії із засобом, орієнтаціями розробників у галузях реклами, комерційної діяльності.

Метою цієї статті є висвітлення психолого-педагогічних і дидактичних чинників у характеристиках для визначення якості програмних засобів навчального призначення на сучасному етапі створення єдиного освітнього простору в Україні в умовах інтенсивного старіння знань з метою виявлення чітких переліків для повних характеристик, які на перспективу складуть підгрунтя для дидактичних і психологопедагогічних вимог для визначення якості ПЗНП.

Саме педагогічний програмний засіб - це програмна продукція, яка використовується у комп'ютеризованих системах освіти як засіб навчання чи виховання учнів і студентів (Наказ МОН № 369 від 15.05 .06 “Про затвердження тимчасових вимог до педагогічних програмних засобів”) [8]. Під якістю педагогічних програмних засобів (ППЗ) на сучасному етапі аксіоматично розуміють ступінь, до якого сукупність властивостей програмного продукту здатна задовольнити конкретні потреби навчального процесу, сприяти досягненню встановлених навчальних цілей. I під час оцінювання зрозуміло звернення до тимчасових вимог щодо педагогічних програмних засобів [8], і порівняння відповідностей саме із цим джерелом, де прописані й основні принципи щодо організації педагогічних програмних засобів навчання:

- відкритість, інтерфейс ППЗ має бути відкритим для взаємодії з іншими інформаційними системами;

- cyмісність, шляхом узгодження змістової частини ППЗ з міжнародними, державними і галузевими (освітянськими) стандартами;

- орієнтація інструментальних засобів на кінцевого користувача: ППЗ повинен бути простим у використанні й доступним для оволодіння людиною, яка має лише загальні навички роботи з комп'ютером; 
- об'єктна організація вмісту, змістова частина ППЗ повинна представлятися у вигляді окремих об'єктів, що дозволить структурувати дані, забезпечити каталогізацію і пошук об'єктів за їхніми властивостями, багаторазово використовувати раніше створені об'єкти даним ППЗ;

- забезпечення прав інтелектуальної власності розробника та замовника ППЗ.

Питання спектру психології комп’ютерного навчання висвітлювалися в працях Б. Г. Ананьєва, Ю. К. Бабанского, В. В. Краєвского, І. Я. Лернера, Г. В. Мухамєтзянової, М. Н. Скаткіна, В. Н. Смирнової, Н. Ф. Тализіної та інших науковців. До всіх без винятку електронних засобів навчання сформульовані такі характеристики:

- відповідність вербально-логічному та сенсорно-периептивним рівням когнітивного проиесу;

- врахування особливостей уваги (стійкість, концеентрація, здатність переключатися, розподіл і обсяг);

- врахування «зони найближчого розвитку», тобто сприяння розвитку того, хто навчається;

- орієнтація на особливості сприйняття (переважно зорового, а також слухового, дотикового);

- орієнтація на словниковий запас та вербально-лінгвістичні можливості певного рівня знань та підготовки дітей, доступність викладення відповідно до віку;

- розвиток мислення (наочно-дійове, образне, словесно-логічне, понятійне, конкретно-понятійне, абстрактно-понятійне або теоретичне);

- розвиток пам’яті (миттєва, довгострокова, короткострокова, оперативна);

- розвиток уяви (мимовільна, довільна, репродуктивна, творча).

У сфері моніторингу якості шкільної освіти відомі праці О. Ляшенко, Т. Лукіної, А. Майорова, М. Поташкіна. Дослідження характеристик програмних засобів навчального призначення, що визначають їхню якість, і методи перевірки цих характеристик вірогідно є найважливішими у цій сфері. Про сукупності дидактичних, психолого-педагогічних, ергономічних вимог свідчать праці I. Роберт, Н. Морзе, I. Вострокнутова, М. Жалдака, В. Лапінського. 
Оскільки програмні засоби навчання є компонентом дидактичної системи, як засоби (рис. 2), тобто відносно програмних засобів навчання справедливо застосування визначень, що і до найважливіших понять дидактики, як науки, які відносяться до основних компонентів процесу навчання.

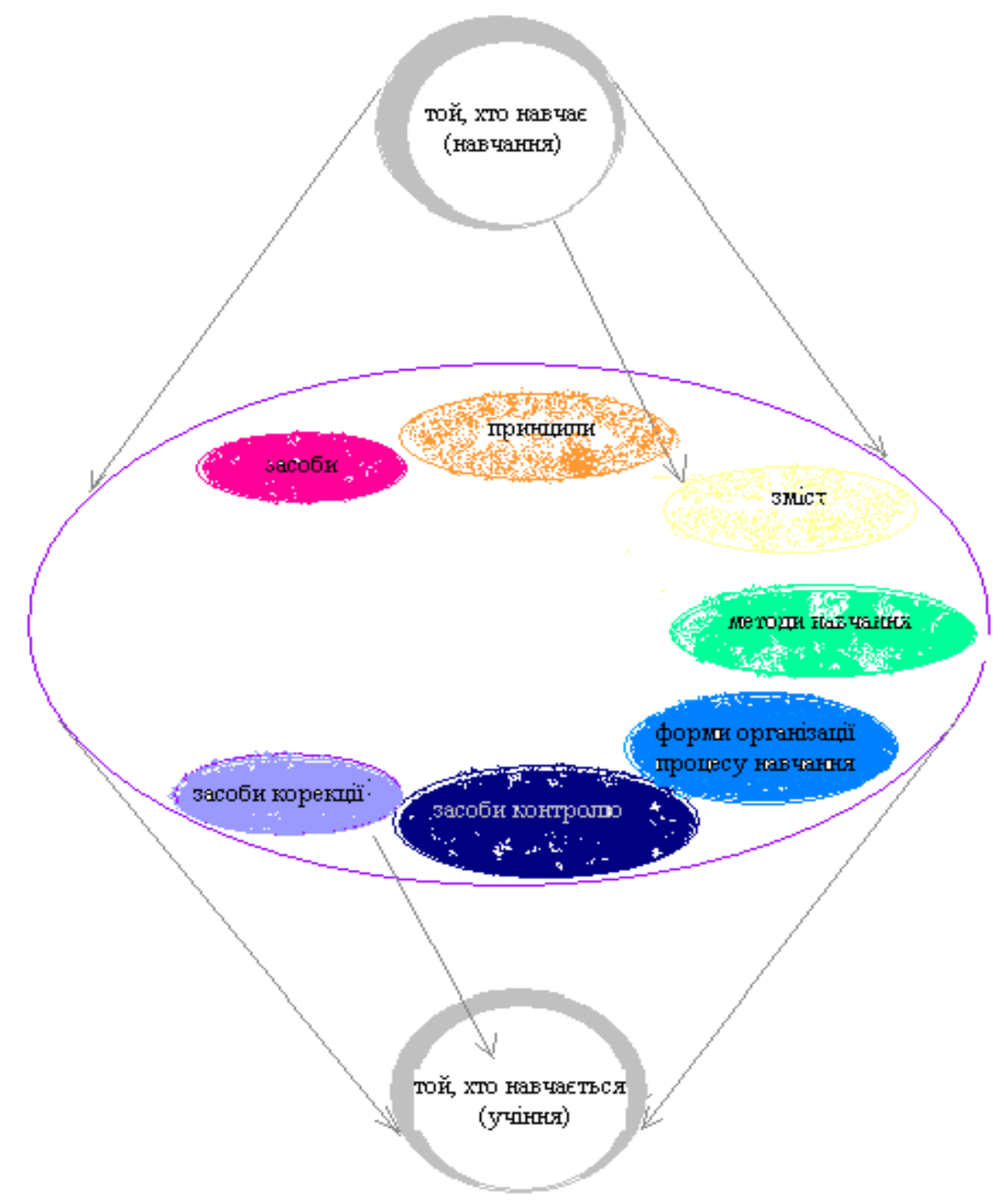

Рис. 2. Компоненти ДС [ 11, с. 26]

У переліку загально-дидактичні:

- доступність навчання, здійснюваного із використанням програмного засобу навчання означає необхідність визначення ступеня і теоретичної складності i глибини вивчення навчального матеріалу згідно вікових i iндивідуальних особливостей тих, хто навчається, неприпустима надмірна ускладненість i перевантаженість навчального матеріалу, за яких оволодіння цим матеріалом стає непосильним для того, хто навчається; 
- науковість навчання із використанням програмних засобів навчання означає достатню глибину, коректність і наукову вірогідність викладу змісту навчального матеріалу, наданого програмним засобом навчання, 3 урахуванням останніх наукових досягнень;

- процес засвоєння навчального матеріалу за допомогою компонентів програмних засобів навчання повинен будуватися відповідно до сучасних методів наукового пізнання: експеримент, порівняння, спостереження, абстрагування, узагальнення, конкретизація, аналогія, дедукція, індукція, аналіз і синтез, методи моделювання, методи системного аналізу;

- наочність навчання означає необхідність урахування почуттєвого сприйняття досліджуваних об'єктів, їхніх макетів чи моделей, їхнє особисте спостереження тим, хто навчається, забезпечення наочності у випадку програмних засобів навчання реалізується на принципово новому, вищому рівні, поширення систем віртуальної реальності дозволяють у найближчому майбутньому вести мову не тільки про наочність, але і про полісенсорність навчання;

- проблемність навчання обумовлена самою сутністю i характером навчально-пізнавальної діяльності, коли учень зіштовхується 3 навчальною проблемною ситуацією, що вимагає вирішення, зростає його розумова активність, рівень виконання цієї дидактичної характеристики за допомогою ПЗНП може бути значно вищим, ніж у разі використання, традиційних підручників і посібників;

- свідомість навчання, самостійність $і$ активізація діяльності тих, хто навчається, передбачає забезпечення навчальним матеріалом самостійних дій учнів щодо використання навчальних даних за чіткого розуміння кінцевих цілей і завдань навчальної діяльності, з усвідомленням для того, хто навчається, саме того змісту, на який спрямована його навчальна діяльність, з діяльнісним підходом в основі, з чіткою моделлю діяльності того, хто навчається, у відповідних інформаційно-комунікаційних ресурсах, 3 адекватністю мотивів діяльності учня змісту навчального матеріалу, 3 метою підвищення активності навчання ПЗНП має генерувати різноманітні навчальні ситуації, з формулюванням різноманітних питань, з можливістю вибору тієї чи іншої траєкторії навчання, можливістю керування ходом подій;

- систематичність і послідовність навчання з використанням ПЗНП означає забезпечення послідовного засвоєння учнями визначеної системи знань у 
досліджуваній предметній галузі; слід зауважити, що знання, уміння, навички мають формуватися у визначеній системі в логічному порядку; для виконання цього необхідним є: подання навчального матеріалу систематизованим і структурованим, 3 урахуванням ретроспективи і перспективи знань, умінь і навичок в організації кожної порції навчальних даних; важливо врахування міжпредметних, міжгалузевих зв’ язків у досліджуваному матеріалі; ретельне обміркування послідовності подання навчального матеріалу і навчальних впливів, аргументації кожного кроку для того хто навчається; побудови процесу одержання знань у послідовності, обумовленій логікою процесу навчання; забезпечення зв'язку даних, представлених ПЗНП, з практикою шляхом підбору прикладів, створення ігрових моментів, надання завдань практичного характеру, експериментів, моделей реальних процесів і явищ;

- $\epsilon$ ність освітніх, розвивальних і виховних функцій навчання у використанні ПЗНП.

Нині на рівні із загальними дидактичними компонентами сформувалися i спец̧ифічні - суто для електронних засобів навчання:

- адаптивність - приймається до уваги пристосованість ПЗНП до індивідуальних можливостей того, кого навчають; розрізняють три рівні адаптації ПЗНП: до першого рівня адаптащиї відносять можливість вибору учнем більш придатного для нього темпу вивчення матеріалу, другий рівень адаптації передбачає діагностику стану того, кого навчають, для вибору змісту і методики навчання за результатами діагностики, третій рівень адаптаџії базується на відкритому підході, щуо не класифікує можливих користувачів і полягає в необхідності прагнення розробки різноманітних варіантів використання для найбільшої кількості тими, кого навчають;

- інтерактивність навчання означає, щзо в прочесі навчання повинна мати місие взаємодія учня з ПЗНП, забезпечення діалогу $i$ зворотного зв'язку між компонентами $і$ підсистемами ПЗНП (важливою частиною організації діалогу постає реакція компонентів ПЗНП на дію користувача), здійснення контролю $i$ корекції дій учня, надання рекомендаџій для подальшої роботи, забезпечення доступу до пояснювальних матеріалів, $i$ контроль з діагностикою помилок із зворотнім зв'язком за результатами навчальної роботи видає аналіз роботи з рекомендаціями для підвищення рівня знань; 
- розвиток інтелектуального потенціалу того, кого навчають, під час роботи з ПЗНП відбувається формування стилів мислення (алгоритмічного, наочнообразного, теоретичного), умінь приймати оптимальні чи варіативні рімення в складній ситуації, уміння обробляти матеріал або дані (на основі використання систем обробки даних, інформаційно-пошукових систем, баз даних і ін.);

- системність $і$ структурно-функціональна поєднаність представлення навчального матеріалу в компонентах ПЗНП;

- забезпечення повноти (цілісності) $i$ безперервності дидактичного иүиклу навчання в ПЗНП означає, щуо ПЗНП повинен надавати можливість виконання всіх ланок дидактичного цุиклу в межах одного сеансу роботи з інформаційною $i$ телекомунікаційною технікою.

Сучасний стан освіти в Україні вимагає розробки нових стратегій розвитку і серйозного реформування на базі перспективних освітніх технологій , спрямованих на підвищення ефективності й підвищення якості освітніх послуг, які надаються. Де головною метою реформування вважатиметься приведення системи освіти у відповідність сучасним потребам суспільства, новим зовнішнім i внутрішнім економічним умовам iï існування. Для збільшення можливостей становлення нової сучасної, так званої постіндустріальної або інформаційної цивілізації, які в першу чергу залежать від рішення проблем у галузі якості освіти й освітніх послуг, де центральне місце обіймає підвищення якості освіти. Стаття В. Г. Кременя [6] і Закон України «Про основні засади розвитку інформаційного суспільства в Україні на 20072015 роки» [5], у якому дана оцінка сучасного стану інформатизації освіти України i визначені основні напрямки іiі розвитку на період до 2015 року, висвітлює основні напрямки реформування освіти України, включаючи розширення доступності освіти, підвищення іï якості і ефективності. У тому числі, думка про підвищення якості освіти посідає центральне місце в концепції модернізації освіти.

\section{Список використаних джерел}

1. Биков В. Ю. Моделі організаційних систем відкритої освіти / В. Ю. Биков // Київ: Атіка, 2009. - 684c.

2. Герчикова И. Н. Менеджмент. / И. Н. Герчикова // М.: Банки и биржи, ЮНИТИ, 1997. - 501 с. 
3. Жалдак M. I. Комп’ютерно-орієнтовані засоби навчання математики, фізики, інформатики / М. І. Жалдак, В. В. Лапінський, М. І. Шут // Київ: Дініт, 2004.

4. Закон України «Про основні засади розвитку інформаційного суспільства в Україні на 2007-2015 роки» від 9 січня 2007 року № 537-V.http://zakon.rada.gov.ua/cgi-bin/laws/main.cgi

5. Кремень В. Г. Суспільство знань і якісна освіта / В. Г. Кремень // Всеукраїнський громадсько-політичний тижневик «Освіта», № 13 - 14, 21-27 березня 2007 p.

6. Освіта в інформаційному поступі суспільства / Доповідь на підсумковій колегії Міністерства освіти і науки України 17 серпня 2006 року // Освіта України. 2006. - 14 серпня (№ 60-61). - С. 1-21.

7. Про затвердження тимчасових вимог до педагогічних програмних засобів Наказ МОН України № 369 від 15.05.06 [Електронний ресурс] - Режим доступу: http://zakon.nau.ua/doc/?uid=1038.1132.0.

8. Титарев Л. Г., Хорошилов А. В. Информационные образовательные технологии и качество образования / Материалы Всероссийской конференции «Роль информационных технологий при обучении на программе МВА» / Л. Г. Титарев, А. В. Хорошилов // Москва: МЭСИ, 30-31 января 2003 г. - С. 241-260.

9. Forrest A. Fifty Ways Towards a Learning Organization. / A. Forrest // London: The Industrial Society, 1999.

10. Стефаненко П. В. Дистанционное обучение в высшей школе: [монография] / П. В. Стефаненко. - Донецк: Дон. НТУ, 2002. - 397 с.

\section{ДИДАКТИЧЕСКИЕ ПРИНЦИПЫ И ПСИХОЛОГИЧЕСКИЕ ХАРАКТЕРИСТИКИ В ОПРЕДЕЛЕНИИ КАЧЕСТВА ПРОГРАМНЫХ СРЕДСТВ УЧЕБНОГО НАЗНАЧЕНИЯ ОБЩЕОБРАЗОВАТЕЛЬНОЙ СРЕДЫ В УКРАИНЕ}

Пирко М. В.

\section{Аннотация}

Фундаментальной особенностью экономики постиндустриального общества есть факт, что знания представляют основной источник конкурентного преимущества. В статье рассмотрен и описан круг дидактических, психологических показателей в исследованиях проблем достижения высокого уровня качества 
образования и образовательных услуг. Обращено внимание на педагогические требования современного периода, которые являются нормативным обоснованием в ориентациях при определении качества программных средств учебного назначения общеобразовательной среды в Украине. Рассмотрена схема внутренней модели обеспечения качества программных средств учебного назначения, перечислены аспекты, интегрируемые внутренней моделью качества программных средств учебного назначения. Упоминается о направлениях исследований в условиях формирования глобальной международной образовательной среды и единого информационного пространства системы образования в русле возростания доступности образовательных услуг. Указано на основные принципы в организации педагогических программных средств обучения.

Ключевые слова: глобальная международная образовательная среда, Государственный Образовательный Стандарт, единое информационное пространство системы образования, дидактические принципы, программные средства учебного назначения, психолого-педагогические требования, оценка качества, качество образования.

\section{DIDACTIC PRINCIPLES AND PSYCHOLOGICAL CHARACTERISTICS IN DEFINITION OF QUALITY OF SOFTWARE TOOLS FOR EDUCATIONAL PURPOSE IN THE GENERAL EDUCATIONAL ENVIRONMENT OF UKRAINE}

Pirko $M$.

\section{Resume}

The fundamental feature of economy of postindustrial society is the knowledge that represents the basic source of competitive advantage. In the article the circle of didactic, psychological indicators in researches of problems of achievement of a high degree of quality of education and educational services is considered and described. The attention is paid to pedagogical requirements of the given period which are a standard substantiation in orientations for quality estimation of software tools for educational purpose of the general educational environment in Ukraine. The scheme of internal model of maintenance of quality of software tools for educational purpose is considered, the aspects integrated by internal model of quality of software for educational purpose are listed. The article describes the directions of researches in the conditions of formation of the global international educational environment and uniform information space of education system taking into 
account the growth of availability of educational services. It is specified the main principles in the organization of pedagogical software tools.

Keywords: global international educational environment, State Educational Standard, global information space of educational system, didactic principles, software tools for educational purpose, psychological-pedagogical requirements, quality estimation, quality of education. 